\title{
Familial thyroglossal duct cyst
}

INSERM

\section{Source}

INSERM. (1999). Orphanet: an online rare disease and orphan drug data base. Familial thyroglossal duct cyst. ORPHA:93953

Familial thyrog lossal duct cyst (TDC) is a very rare inherited form of TDC characterized by a mass measuring $3 \mathrm{~cm}$ in diameter or less in the midline area of the neck. 